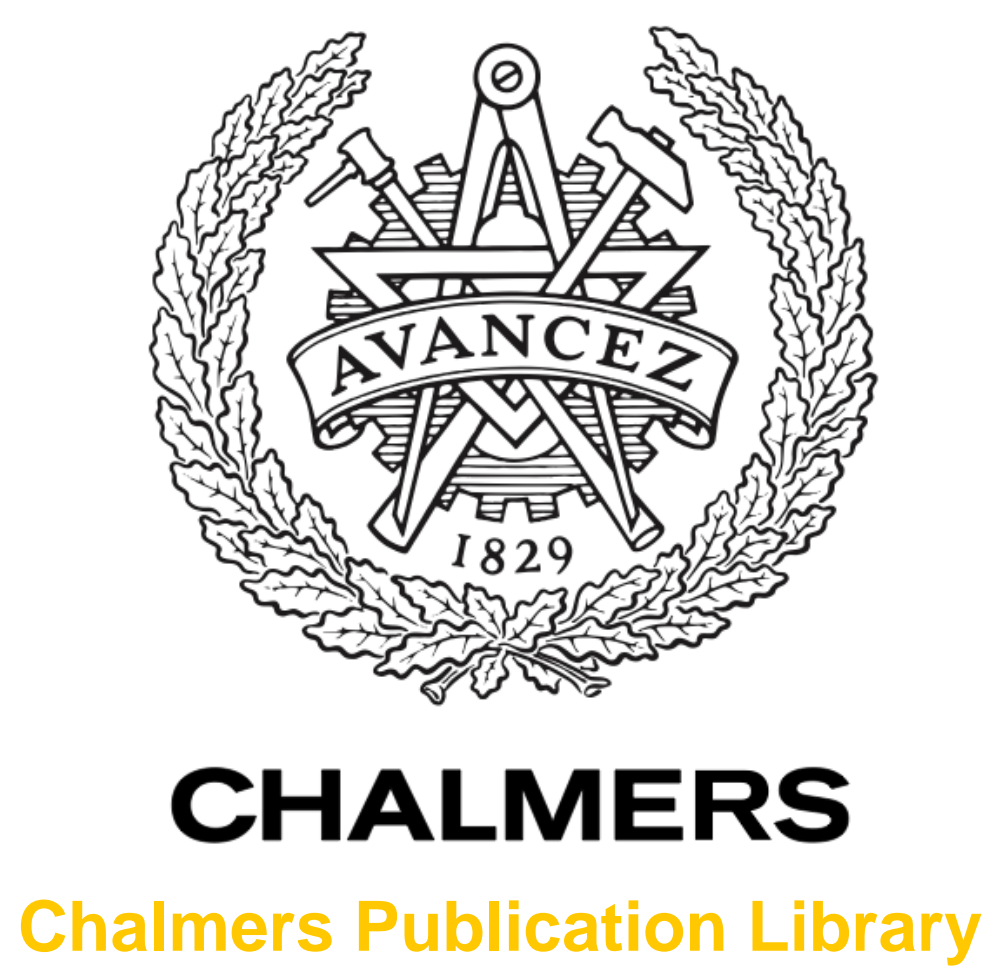

\title{
Anchorage of naturally corroded bars in reinforced concrete structures
}

This document has been downloaded from Chalmers Publication Library (CPL). It is the author's version of a work that was accepted for publication in:

Magazine of Concrete Research (ISSN: 0024-9831)

Citation for the published paper:

Tahershamsi, M. ; Zandi Hanjari, K. ; Lundgren, K. et al. (2014) "Anchorage of naturally corroded bars in reinforced concrete structures". Magazine of Concrete Research

http://dx.doi.org/10.1680/macr.13.00276

Downloaded from: http://publications.lib.chalmers.se/publication/198358

Notice: Changes introduced as a result of publishing processes such as copy-editing and formatting may not be reflected in this document. For a definitive version of this work, please refer to the published source. Please note that access to the published version might require a subscription.

Chalmers Publication Library (CPL) offers the possibility of retrieving research publications produced at Chalmers University of Technology. It covers all types of publications: articles, dissertations, licentiate theses, masters theses, conference papers, reports etc. Since 2006 it is the official tool for Chalmers official publication statistics. To ensure that Chalmers research results are disseminated as widely as possible, an Open Access Policy has been adopted.

The CPL service is administrated and maintained by Chalmers Library. 
Magazine of Concrete Research Volume 66 Issue 14

Anchorage of naturally corroded bars in reinforced concrete structures

Tahershamsi, Zandi, Lundgren and Plos
Magazine of Concrete Research, 2014, 66(14), 729-744

http://dx.doi.org/10.1680/macr.13.00276

Paper 1300276

Received 07/10/2013; revised 02/01/2014; accepted 05/03/2014

Published online ahead of print 20/05/2014

ICE Publishing: All rights reserved

\section{Anchorage of naturally corroded bars in reinforced concrete structures}

\section{Mohammad Tahershamsi}

MSc-Doctoral candidate, Department of Civil and Environmental Engineering, Division of Structural Engineering, Concrete Structures, Chalmers University of Technology, Gothenburg, Sweden

Kamyab Zandi

PhD Researcher, Materials Group, CBI Swedish Cement and Concrete Research Institute, Borås, Sweden; Research Assistant, Department of Civil and Environmental Engineering, Division of Structural Engineering, Concrete Structures, Chalmers University of Technology, Gothenburg, Sweden

\section{Karin Lundgren}

Professor, Department of Civil and Environmental Engineering, Division of Structural Engineering, Concrete Structures, Chalmers University of Technology, Gothenburg, Sweden

\section{Mario Plos}

Associate Professor, Department of Civil and Environmental Engineering, Division of Structural Engineering, Concrete Structures, Chalmers University of Technology, Gothenburg, Sweden

The bond properties of naturally corroded reinforced concrete members were experimentally investigated. Thirteen specimens were taken from the northern edge beam of Stallbacka Bridge, a girder bridge in Sweden. The specimens exhibited different levels of corrosion-induced damage, including concrete cracking and cover spalling. The damage was carefully documented and the specimens were tested in suspended four-point bending tests. Their general behaviour was monitored through measurements of applied loads and vertical deflections. At the same time, the local anchorage behaviour was recorded at the end regions. The test results showed around $5 \%$ lower anchorage capacity for damaged specimens compared with the reference ones. The residual bond strength was studied with respect to the observed damage. These tests, and artificial corrosion results from the literature, indicate that the bond strength decreased with increasing maximum splitting crack widths. However, the bond capacity was higher for the naturally corroded specimens. The results thus show an obvious difference between artificial and natural corrosion, and furthermore indicate that the provisions given in fib Model Code 2010 are on the safe side. These test results contribute to further knowledge regarding the structural behaviour of corroded reinforced concrete structures.

\section{Notation}

d effective cross-sectional height

$F_{\mathrm{t}} \quad$ estimated tensile force in tensile bars

$f_{\mathrm{c}} \quad$ compressive strength of cylindrical concrete specimen

$l_{\mathrm{a}} \quad$ available anchorage length

$l_{\mathrm{s}} \quad$ shear span length

$P \quad$ applied single load from load cell

$\phi \quad$ main bar diameter

\section{Introduction}

Deterioration caused by aggressive agents is a very common, serious and costly problem in existing concrete structures. Almost all types of structural concrete contain steel in the form of reinforcements or tendons or a combination of both. Corrosion of these steel components leads to several undesirable effects in a concrete member. One possible severe damage state is a loss in steel cross-sectional area, which reduces both the capacity and the ductility of the reinforcement (Almusallam, 2001; Du et al., 2005a, 2005b). Corrosion of embedded steel reinforcement also damages the surrounding concrete. Corrosion products occupy a much higher volume than the original steel, which increases the pressure around the reinforcement. This results in concrete crack- ing, cover spalling and degradation of reinforcement-concrete bond properties (Al-Sulaimani et al., 1990). Such defects occurring in the anchorage zones of load-carrying members can significantly affect the mechanical performance of a structure (Regan and Kennedy Reid, 2010; Zandi Hanjari et al., 2011a). Loss of ductility and stiffness during the service life (Coronelli and Gambarova, 2004; Zandi Hanjari et al., 2011b) and a decrease in load-carrying capacity in the ultimate limit state (Val et al., 2009) are among the main structural issues observed in cases of corrosion damage.

Numerous studies have investigated the parameters that may influence the bond and anchorage capacity of corroded reinforced concrete (for the latest findings see work by Coronelli et al. (2013), Regan and Kennedy Reid (2010), Sæther (2011) and Zandi Hanjari et al. (2011b)). However, existing knowledge is mostly based on experimental investigations of specimens that have been subjected to accelerated corrosion, for example by application of impressed current density. The current densities applied in laboratory work usually vary in the range 0.05$5.00 \mathrm{~mA} / \mathrm{cm}^{2}$, which is noticeably higher than natural values measured in the field, and deterioration caused by artificial 
corrosion may affect the structural behaviour in different ways compared with natural corrosion

Experimental evidence reported in the literature shows that common methods of accelerated induced corrosion may influence the bond capacity and change the anchorage behaviour (Austin et al., 2004; Saifullah and Clark, 1994). Yuan et al. (2007) found that the corroded steel surface morphology was homogeneous in accelerated corrosion tests while, in natural corrosion conditions, the steel surface corroded heterogeneously. Furthermore, the longer time span required for natural corrosion means that time-dependent effects (e.g. shrinkage, creep and the transport of corrosion products through cracks) will differ. Furthermore, in many countries, freezing will affect the natural behaviour. Nevertheless, the strong justification for using accelerated induced corrosion in laboratory tests is the reduction of corrosion time from several decades to a few weeks. To better correspond to reality, it has been suggested that artificial corrosion tests should be carried out using relatively low current densities, such as $0.05 \mathrm{~mA} / \mathrm{cm}^{2}$ (Coronelli, 1997), and that the results should be interpreted and extrapolated to field practice with great care. There is thus a strong requirement for experiments on natural corrosion to facilitate evaluation of the accelerated corrosion tests available in the literature.

As the process of natural corrosion takes several years, corroded specimens from existing structures were collected. In two series of tests, the anchorage capacity of naturally corroded steel bars embedded in concrete was investigated. In the first test series, eight specimens with different degrees of corrosion damage were taken from the southern edge beam of the concrete deck of Stallbacka Bridge. An appropriate test setup was designed (Berg and Johansson, 2011) and the specimens were tested successfully. The results of the first test series showed almost $10 \%$ lower load-carrying capacity for the corroded specimens than for undamaged ones (Lundgren et al., 2014; Tahershamsi et al., 2012a, 2012b)

The results of the second series of experiments are presented and analysed in this paper. Thirteen specimens were taken from the northern edge beam of Stallbacka Bridge and tested in a similar four-point bending test configuration, indirectly supported by suspension hangers, as in the first test series. The corrosion process had taken place naturally over approximately 30 years of the bridge service life. The anchorage behaviour of the reinforcement was investigated through measurements of the applied load, free-end slip and mid-span deflection. The aim of the experiments was to study the influence of natural corrosion on the mechanical behaviour of damaged concrete members, particularly the anchorage capacity. In this study, an effort was made to understand the correlations between the visually observed corrosion damage and the anchorage capacity and to form a basis for comparison of natural versus accelerated corrosion test data.

\section{Test specimens}

The specimens were chosen from the concrete edge beams of a steel girder bridge with a concrete deck slab. The bridge, Stallbacka Bridge, is located in the south-west of Sweden in an aggressive environment due to the use of de-icing salt during the winter. For this reason, corrosion was considered as the main cause of deterioration. Despite the fact that the bridge was built only 30 years ago, it was impaired by the severity of the deterioration and the outermost part of the cantilevering deck and the edge beams were replaced in a rehabilitation project from 2010 to 2012. When constructed, the bridge deck was cast in segments with cast joints in the transversal direction of the bridge, through both bridge slab and the edge beams. The amount of reinforcement across these joints in the slab was insufficient and therefore the edge beams were subjected to more load than they were designed for, leading to the appearance of large cracks. To prevent moisture and snow freezing on the bridge deck, deicing salt was applied. Chlorides from the de-icing salt reached the steel bars through the load-induced cracks in the concrete. Furthermore, transverse cracks at the construction joints may have accelerated chloride penetration.

The edge beams along the bridge deck showed different amounts of corrosion-induced damage, from no sign of corrosion to extensive cover cracking, resulting in spalling of the concrete cover. This was considered to be an advantage for specimen selection since it was thus possible to acquire specimens with varying levels of damage. Based on the damage patterns, the test specimens were sorted into three groups

reference (R) specimens without any visible cracks

- specimens with medium damage (M) (spalling cracks)

- specimens with a high degree of damage $(\mathrm{H})$ (cover spalling).

In the first test series, large variations were observed in the capacity of the $\mathrm{M}$ specimens. Therefore, in this test series, more specimens of type $\mathrm{M}$ were selected.

The geometry of the edge beams was suitable for bending tests, which made it possible to evaluate the anchorage behaviour at a structural level. Figure 1 shows the geometry of the edge beams. The cross-section of the beams was $350 \times 400 \mathrm{~mm}^{2}$, with a small inclination of the upper surface. Both longitudinal and transversal reinforcements in the edge beams were ribbed. The studied tensile reinforcements were four bars of $\varnothing 16 \mathrm{Ks} 60$ bundled in pairs, see Table 1. The transverse reinforcement consisted of stirrups $\varnothing 10 \mathrm{Ks} 40$ with a spacing of $300 \mathrm{~mm}$. Due to differing precision in the construction stage, the concrete cover of the longitudinal reinforcement varied (see Table 2 and Figure 2). No sign of corrosion was observed around the longitudinal reinforcement bars close to the bottom surface of the edge beams. The longitudinal reinforcement bars closest to the upper inclined surface of the edge beams were severely damaged as they were the most exposed to de-icing salt; these were therefore more relevant for investigation of bond and anchorage behaviour. 


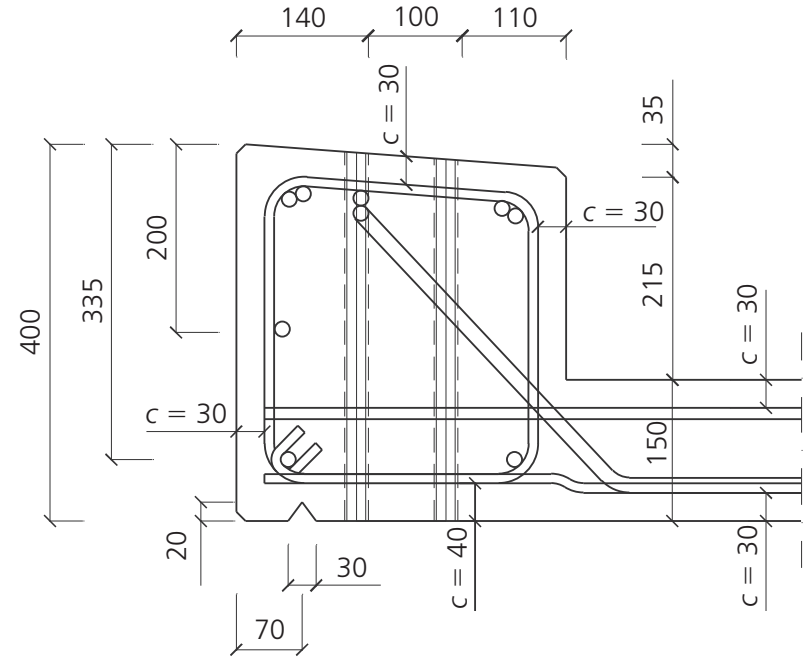

Figure 1. Cross-sectional details of the edge beam, adapted from bridge drawings. All dimensions are in $\mathrm{mm}$; $\mathrm{c}$ is cover thickness

\begin{tabular}{ll}
\hline Reinforcement type & Specification \\
\hline Longitudinal bars (inclined surface) & $4 \varnothing 16 \mathrm{Ks} 60$ bundled \\
Longitudinal bars (levelled surface) & $2 \varnothing 16 \mathrm{Ks} 60$ \\
Longitudinal bar (at mid-height) & $1 \varnothing 16 \mathrm{Ks} 60$ \\
Stirrups & $\varnothing 10 \mathrm{Ks} 40$, spacing \\
& $300 \mathrm{~mm}$ \\
Strengthening bars & $\varnothing 10$ Dywidags
\end{tabular}

Table 1. Reinforcement details

\begin{tabular}{lcccc}
\hline Specimen & $c_{a}: m m$ & $c_{b}: m m$ & $c_{c}: m m$ & $c_{d}: m m$ \\
\hline R4 & 60 & 48 & 45 & 65 \\
R6 & 58 & 57 & 56 & 45 \\
M4 & 70 & 45 & 40 & 65 \\
M5 & 60 & 42 & 46 & 64 \\
M7 & 31 & 74 & 60 & 51 \\
M8 & 45 & 45 & 60 & 40 \\
M9 & 45 & 50 & 55 & 50 \\
M10 & 50 & 55 & 45 & 60 \\
M11 & 62 & 73 & 35 & 69 \\
M12 & 32 & 85 & 62 & 60 \\
H5 & 68 & 30 & 55 & 54 \\
H6 & 72 & 54 & 39 & 60 \\
H7 & 30 & 70 & 65 & 50
\end{tabular}

Table 2. Size of concrete covers in the failure region of the tested specimen

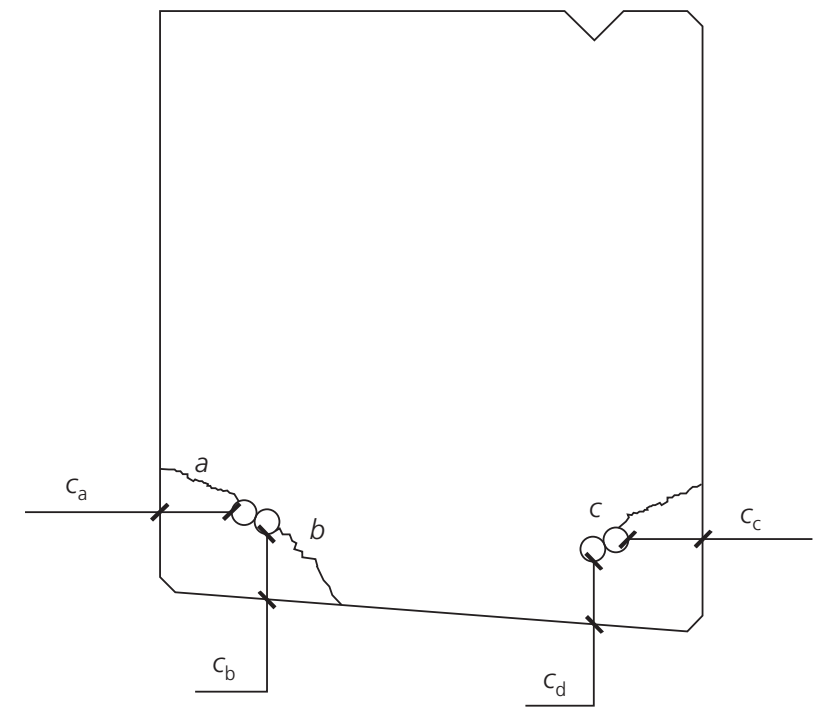

Figure 2. Concrete cover and spalling crack notations; the orientation of the cross-section in the test rig is also shown

\section{Experimental details}

All the beam tests were carried out at the Structural Engineering Laboratory of Chalmers University of Technology. Based on experience obtained from the first test series, the measurements in the tests were slightly modified, as described later in the paper. Crack and spalling patterns were documented before, during and after the tests. Material tests were carried out on drilled cores, and the beams were saved after testing for measurements of the corrosion level and reinforcement tensile tests.

\section{Material properties}

In the second test series, only cores of suspension holes were drilled out. Drilling of the specimens was performed according to BS EN 12504-1:2009. Cylindrical cores of $110 \mathrm{~mm}$ height and $55 \mathrm{~mm}$ diameter were used in compression tests. The tests on cylindrical compressive strength were performed according to BS EN 12390-3:2009; the results are given in Table 3. The average compressive strengths of the $\mathrm{H}$ and $\mathrm{M}$ specimens were approximately $85-90 \%$ of the strength of the R specimens. It may thus be concluded that the lower concrete strength could have influenced the damage level.

\section{Experimental setup}

The test configuration was designed to secure anchorage failure for beams with different degrees of corrosion damage in one common test setup (Berg and Johansson, 2011). A four-point bending test indirectly supported by suspension hangers was chosen (Figure 3). Since it was considered important to have the suspension holes positioned between two stirrups, the holes were located in advance. In some cases, it was necessary to move the support hole closer to the centre of the specimen in order not to drill the outermost stirrups. In such cases, the two support holes were both moved closer to the centre to maintain symmetry of 


Specimen $\quad f_{\mathrm{c}}$ : MPa $\begin{array}{cc}\text { Average } f_{\mathrm{c}}: & \text { Standard } \\ \mathrm{MPa} & \text { deviation: MPa }\end{array}$

Reference (R)

R4-1

$48 \cdot 0$

R4-2

$49 \cdot 2$

R4-3

$60 \cdot 0$

R6-1

$54 \cdot 5$

R6-2

$53 \cdot 0$

R6-3

$46 \cdot 2$

$51 \cdot 8$

$5 \cdot 1$

Medium damage (M)

M4-1

$56 \cdot 1$

$\mathrm{M} 4-2$

$45 \cdot 1$

M5

-

M7-1

$37 \cdot 5$

M7-2

$44 \cdot 2$

M7-3

42.9

M7-4

$45 \cdot 8$

M8-1

59.7

M8-2

48.6

M8-3

$52 \cdot 7$

M9-1

33.9

$50 \cdot 1$

M9-2

$50 \cdot 6$

M10-1

$52 \cdot 6$

M10-2

$40 \cdot 2$

M11-1

$31 \cdot 8$

M11-2

$52 \cdot 4$

$48 \cdot 5$

37.9

M12-1

$\mathrm{M} 12-2$

43.9

High damage $(\mathrm{H})$

H5-1

$50 \cdot 0$

H6-1

$49 \cdot 2$

$37 \cdot 1$

$39 \cdot 2$

H6-3

H7-1

47.9

H7-2

$33 \cdot 1$

$42 \cdot 8$

Table 3. Compressive strength test results of core specimens taken from the edge beams

the specimens. Thus, the span length between the supports varied slightly (see Figure 3 and Table 4). However, the shear span was kept constant and equal to $570 \mathrm{~mm}$.

The edge beams were strengthened by four transverse reinforcements on each side of the suspension holes to avoid premature failure of the beams in the support regions. Steel bars of $\varnothing 20 \mathrm{~mm}$ were injected in the drilled cores with epoxy to strengthen the support region. These strengthening bars were anchored at the top of the beam using hexagonal nuts and flat steel plates (Figure 3). The mechanical locking of the bars, by means of threaded coupling, provided adequate anchorage to avoid failure at the suspension holes. In the first test series, the support settlements were measured on top of the flat steel plates, but these measurements also included the settlements between the steel plates and the beam. To avoid this problem in the second series, the steel plates were drilled in certain locations and the linear variable differential transformers (LVDTs) at the supports were set on top of the concrete surface.

The load was applied by two symmetrically placed hydraulic jacks connected to one hydraulic pump to yield equally large loads. Each of the loads was measured by load cells placed on the top of each jack. Steel plates and wood-fibre plates were placed between the hydraulic jacks and the beam; the plates' dimensions were $100 \mathrm{~mm}$ along the beam and $250 \mathrm{~mm}$ across the beam. The tests were conducted by controlling the displacement in the mid-span. Displacement transducers measured the vertical displacements relative to the floor in mid-span, in sections of the suspensions, and at the loads. Furthermore, one displacement transducer per main bar was placed on the short face of the beam ends to measure the free-end slip of the longitudinal reinforcement. Two displacement transducers were used to measure the displacement of the concrete at approximately the same level as the main bars. These end slips and concrete cross-sectional displacements were measured relative to a point on the short face of the beam end, located $185 \mathrm{~mm}$ from the top of the beam. All measurements were continuously stored in a datalogger with an amplitude of $1 \mathrm{~Hz}$. To avoid unexpected settlements during the tests, all specimens were loaded up to $35 \mathrm{kN}$ and then unloaded. Thereafter, loading was applied in steps and the crack development was continuously registered up to the failure load.

In summary, modifications of the tests compared to the first test series were applied mostly to the measurement system. First, the true support settlements were measured by adjusting the strengthening steel plates and placing the displacement transducers on the top surface of the beams. Second, the displacement of the concrete close to the main bars was measured to enable more correct evaluation of the free-end slip; for more information see Gestsdottir and Gudmundsson (2012).

\section{Results}

\section{Documentation of damage before tests}

Before the experiments, all visible cracks were marked and measured. For most of the specimens, the crack widths were first measured on the bridge. After moving the samples to the laboratory, the crack widths and spalled concrete covers were thoroughly documented for a second time, for all specimens. Comparison of the crack widths from the two measurements, on the bridge and in the lab, showed minor differences for most specimens. Some measured crack widths had widened by up to $0.5 \mathrm{~mm}$. However, a few crack widths measured in the lab were narrower than the values recorded on the bridge. From the measurements just before structural testing, the crack widths of the splitting cracks, measured on the sides that later failed, varied 


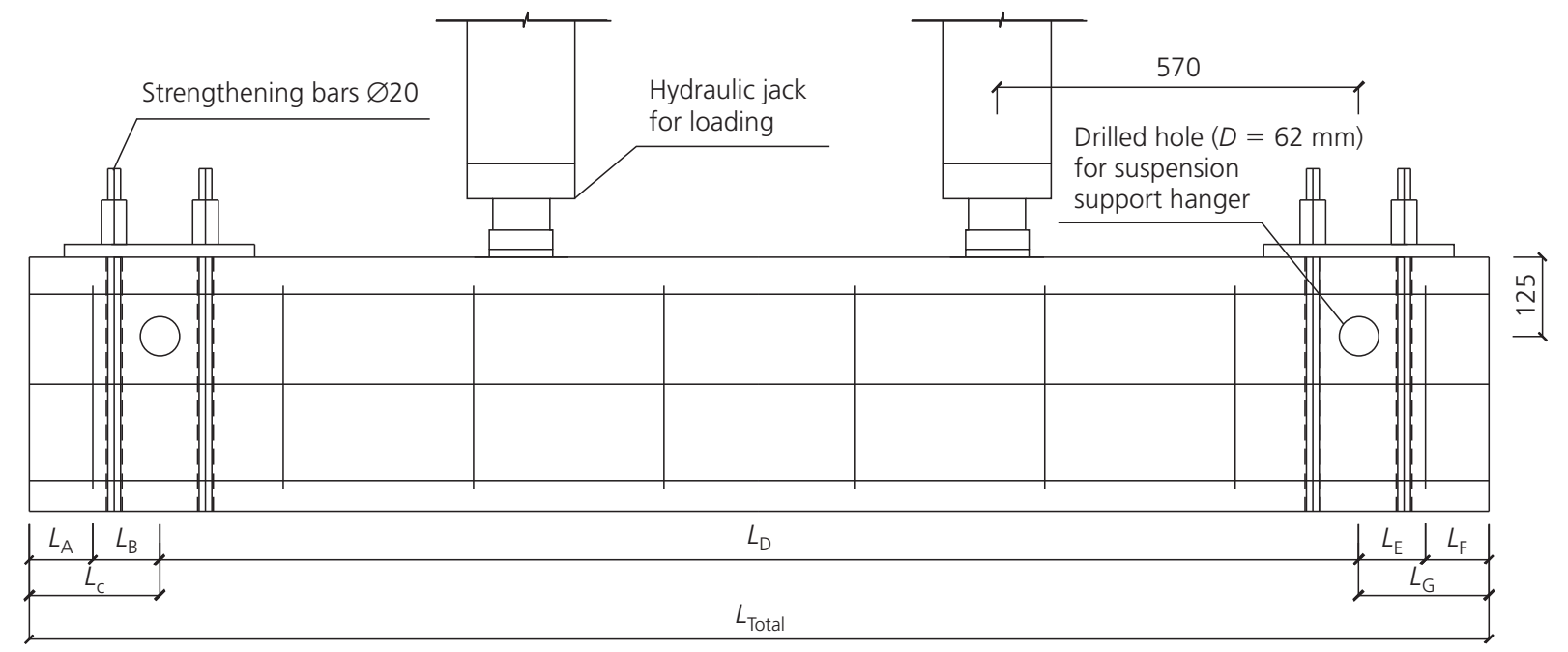

Figure 3. Symmetrical test setup showing the test specimen, loading jacks and holes for suspension support (dimensions in $\mathrm{mm}$ )

\begin{tabular}{lrrrrrrrr}
\hline Specimen & $L_{A}: m m$ & $L_{B}: m m$ & $L_{C}: m m$ & $L_{D}: m m$ & $L_{E}: m m$ & $L_{F}: m m$ & $L_{G}: m m$ & $L_{\text {Total: } m m}$ \\
\hline R4 & 80 & 125 & 205 & 1870 & 110 & 95 & 205 & 2280 \\
R6 & 140 & 110 & 250 & 1815 & 185 & 65 & 250 & 2315 \\
M4 & 105 & 100 & 205 & 1875 & 165 & 40 & 250 & 2285 \\
M5 & 139 & 86 & 225 & 1882 & 129 & 96 & 225 & 2332 \\
M7 & 110 & 95 & 205 & 1893 & 120 & 85 & 205 & 2303 \\
M8 & 95 & 135 & 230 & 1840 & 130 & 100 & 230 & 2300 \\
M9 & 85 & 120 & 205 & 1878 & 110 & 95 & 205 & 2288 \\
M10 & 115 & 100 & 215 & 1860 & 135 & 80 & 215 & 2290 \\
M11 & 100 & 95 & 195 & 1886 & 85 & 110 & 195 & 2276 \\
M12 & 110 & 95 & 205 & 1885 & 110 & 95 & 205 & 2295 \\
H5 & 80 & 125 & 205 & 1890 & 115 & 90 & 205 & 2300 \\
H6 & 130 & 110 & 240 & 1800 & 190 & 50 & 240 & 2280 \\
H7 & 100 & 130 & 230 & 1855 & 105 & 125 & 230 & 2315
\end{tabular}

Table 4. Measured dimensions of the test specimens (see Figure 3)

from $0.1 \mathrm{~mm}$ to $1.5 \mathrm{~mm}$ (see Table 5 and Figure 2). Some examples of the damaged specimens are shown in Figure 4.

\section{General behaviour of the test specimens}

In total, thirteen specimens were tested. The specimens showed similar behaviour concerning crack propagation and failure mode, while the stiffness and maximum loads varied slightly. Splittinginduced pull-out was the failure mode in all tested specimens. Figure 5 shows an example of the results for one of the test specimens, M4. In these tests, the first flexural cracks were observed at around $65-95 \mathrm{kN}$. At this load level, some cracks propagated around the suspension holes. As the load was increased, some flexural-shear cracks grew over the shear span. The first inclined shear crack was observed at around $135-155 \mathrm{kN}$ (see Table 6). As the load increased, the anchorage zones gradually became loaded. The bond between the reinforcement and the concrete activated and the free end of the reinforcement bars started to slip at load levels of $200-220 \mathrm{kN}$. At this load level, a second shear crack was observed in some test specimens. When failure was approaching, splitting cracks occurred on the side of the beam that later failed in the anchorage zone around the main bars. However, in specimens H5 and M10, a few splitting cracks also propagated on the side of the beam that did not fail. Final anchorage failures occurred on average at load levels of $281 \mathrm{kN}, 267 \mathrm{kN}$ and $266 \mathrm{kN}$ for R, M and $\mathrm{H}$ specimens respectively (Table 7). 


\begin{tabular}{lccc}
\hline \multirow{2}{*}{ Specimen } & \multicolumn{3}{c}{ Crack width: mm } \\
\cline { 2 - 4 } & $a$ & $b$ & $c$ \\
\hline R4 & - & - & - \\
R6 & - & - & - \\
M4 & Damaged a & Damaged a & - \\
M5 & 0.6 & $0 \cdot 2$ & - \\
M7 & 1.5 & - & $0 \cdot 2$ \\
M8 & 0.7 & - & - \\
M9 & - & - & - \\
M10 & 1.4 & - & - \\
M11 & 0.9 & - & - \\
M12 & 1.5 & $0 \cdot 1$ & - \\
H5 & 1.5 & - & - \\
H6 & Spalling & Spalling & - \\
H7 & Spalling & Spalling & - \\
\hline
\end{tabular}

a Spalling of concrete cover occurred in preparation stage.

Table 5. Observed crack width in the anchorage zone before testing, on the side of the specimen that failed in tests (see Figure 2)

The two R specimens showed rather different results. Photographs of some of the tested beams are shown in Figure 6. During the preparation stage, specimens M4 and M8 were slightly damaged and the concrete cover was spalled at one corner (Figure 4). Therefore, these specimens were regrouped into the $\mathrm{H}$ category. However, in M8, anchorage failure occurred on the side with no cover spalling. As mentioned earlier, in specimen M10, splitting cracks propagated on two sides. On the side where the splitting cracks first occurred, one of the bundled bars at one corner started to slip and, later, anchorage failure occurred on the other side. For the $\mathrm{H}$ specimens, beams $\mathrm{H} 6$ and $\mathrm{H} 7$ failed on the side with cover spalling, while failure occurred on the side with the splitting cracks in specimen H5. In specimen R4, rather large deflection was observed in the initial loading stage (Figure 7(a)). This behaviour could be partly related to existing damage due to freezing of the specimen. Zandi Hanjari et al. (2013) explained the phenomenon as the soft behaviour of damaged concrete in the compression zone, which might result in large mid-span deflections.

\section{Available anchorage length}

In four-point bending tests, flexural and shear cracks occur in the shear span with an increase of load. After the occurrence of inclined cracks, the tensile force in the reinforcement in the shear span increases. This tensile force in the reinforcement must be transferred to the concrete by bond stresses, and this is called the anchorage (Magnusson, 2000). Based on this definition, the available anchorage length was measured from the crack patterns that appeared after the tests: it was measured from the point where the inclined shear crack met the tensile reinforcement bars to the end cross-section (see examples in Figure 8). Measurements were taken on the sides of the beam that failed, both rear and front sides. The average anchorage lengths for rear and front sides are listed in Table 8 . As can be seen, the values vary from about $250 \mathrm{~mm}$ to $500 \mathrm{~mm}$. The available anchorage length showed a lower average value for the $\mathrm{R}$ specimens than for the $\mathrm{M}$ and $\mathrm{H}$ beams. As discussed earlier, for some of the beams, it was necessary to move the support holes closer to the centre in order not to damage the stirrups (Table 4). However, these small variations in geometry did not seem to influence the available anchorage length.

\section{Calculation of average bond stress}

The average bond stress along the bundled bars was estimated as follows. The axial force in the longitudinal reinforcement bars was calculated assuming that no tensile force was transferred over the main shear crack (see Figure 9). The inner lever arm was assumed to be $0 \cdot 9 d$, in which the effective height $d$ was taken as the distance between the top of the cross-section to the average position of the tensile reinforcement bars. From equilibrium, the tensile force in the longitudinal reinforcement was thus calculated as

1. $\quad F_{\mathrm{t}}=\frac{P l_{\mathrm{s}}}{0 \cdot 9 d}$

where $P$ represents the point load and $l_{\mathrm{s}}$ the shear span, which was $570 \mathrm{~mm}$ in all the tests. The average bond stress along the bundled bars was then calculated based on the tensile force $P$, the available anchorage length $l_{\mathrm{a}}$ and the circumference of the bundled bars. For the circumference of two bundled bars, Jirsa et al. (1995) used an upper and lower limit of $\phi 2 \pi$ and $\phi(\pi+2)$ respectively. In this study, the average value of this upper and lower limit was chosen. Since there were two bundles of two bars each, the average bond stress was calculated as

2. $\hat{\tau}=\frac{F_{\mathrm{t}}}{l_{\mathrm{a}}(3 \pi+2) \phi}$

where $l_{a}$ is the available anchorage length, evaluated as described earlier. More details concerning the calculations are given by Lundgren et al. (2014). The maximum average bond stress of all tests is given in Table 9. The highest bond stress was found in the undamaged specimens. Compared with the $\mathrm{R}$ specimens, the $\mathrm{M}$ specimens had almost $17 \%$ lower maximum bond stress and the $\mathrm{H}$ specimens showed a $13 \%$ decrease.

Figures 7, 10 and 11 show the calculated average bond stress versus measured average free-end slip for $\mathrm{R}, \mathrm{M}$ and $\mathrm{H}$ specimens respectively (measurement noises were filtered out). It should be noted that the measured slips were all negative for the first test series (Lundgren et al., 2014) and also for the first test in this series (M5) (see Figure 10). The problem was solved in the other tests of this series by measuring the deformation of the concrete 
Anchorage of naturally corroded bars in

reinforced concrete structures

Tahershamsi, Zandi, Lundgren and Plos

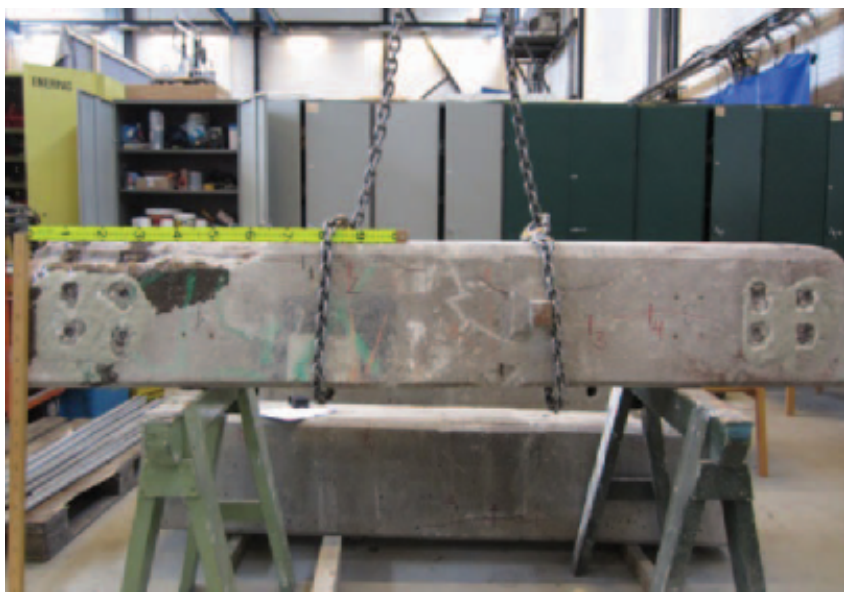

(a) M4

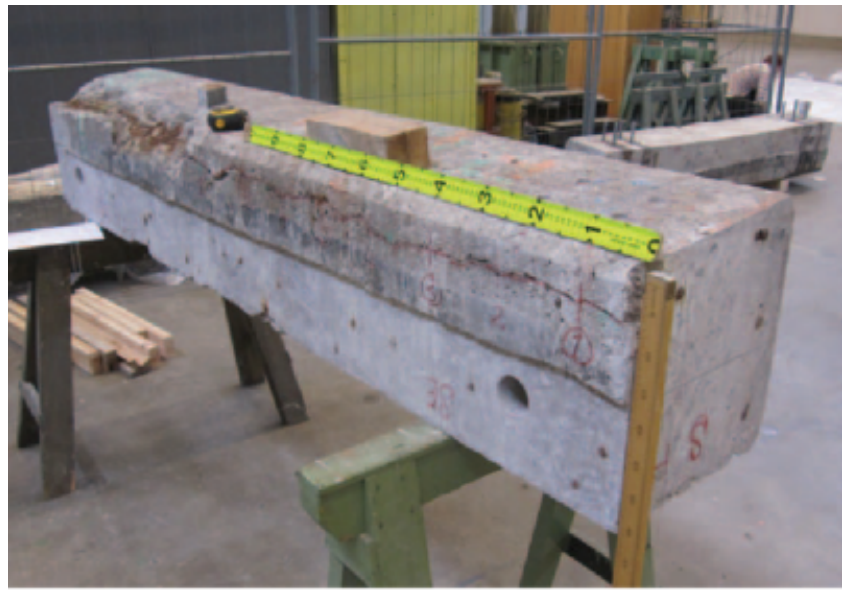

(c) H5 (spalled concrete cover)

Figure 4. Examples of documentation of damage before testing: (a) M4; (b) M8 (concrete cover spalled in one corner during the preparation stage); (c) H5 with severe concrete cover spalling,

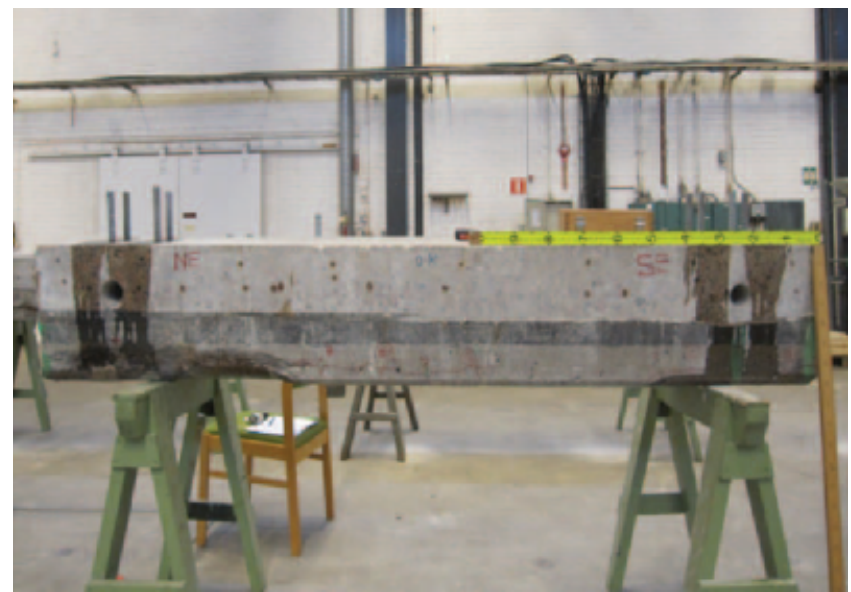

(b) M8

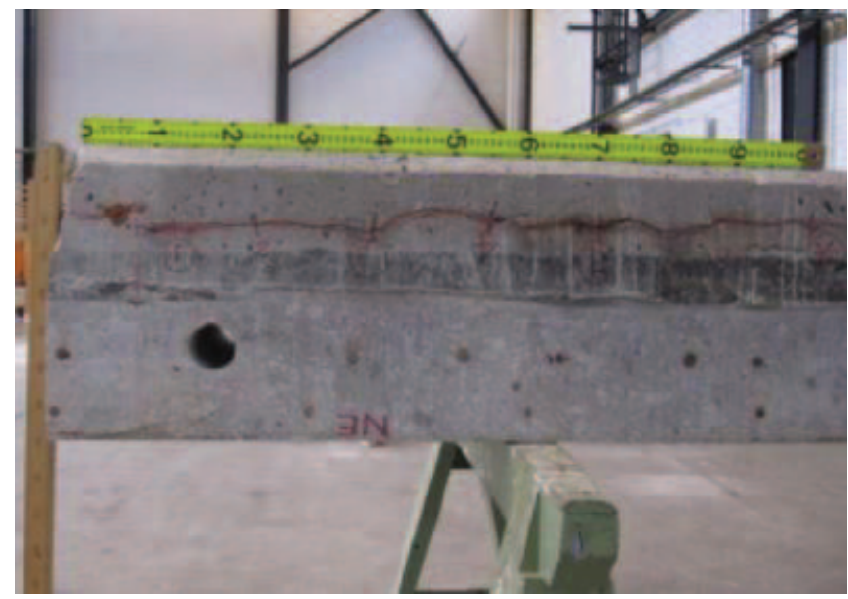

(d) M12

which failed on the side with only splitting cracks; (d) M12 with a continuous splitting crack along the failure side cross-section close to the main bars, as mentioned earlier in the paper. For these tests, the slip values were corrected by these measurements. The results clearly showed the initiation points as well as the magnitudes and rates of the increasing slips. As can be seen in Figure 7, for the $\mathrm{R}$ specimens, the average end slip started increasing at load levels higher than the initial shear cracks and rather close to the maximum failure load, around $90 \%$ of the maximum load. For the $\mathrm{M}$ specimens, the free-end slip started at about $75-95 \%$ of the maximum load and the slip values increased up to $0 \cdot 1-0 \cdot 8 \mathrm{~mm}$ in different tests (Figure 10). In specimens $\mathrm{H} 6$ and $\mathrm{H} 7$, the post-peak behaviour was more stable and the slip values increased up to $2.5 \mathrm{~mm}$. For specimen $\mathrm{H} 5$, in which failure occurred on the side without cover spalling, the anchorage of the main bars failed in a more brittle manner (Figure 11). A comparison of beams within each category revealed that the specimens with relatively lower stiffness in the load-deformation graphs had a more stable increase of slip reaching a maximum load and, furthermore, they showed slightly larger slips at post-peak behaviour. For example, in Figure 7, R4 showed larger deflections for the applied load compared with R6 and the main tensile reinforcements in R4 also showed more ductile bond behaviour. A residual bond capacity of around 50$70 \%$ of the maximum bond capacity was observed for large slip values in most of the tests.

\section{Discussion}

In total, 21 specimens with differing degrees of corrosion damage were tested in the first test series (Lundgren et al., 2014) and the second test series. In both series, the damaged specimens showed around $5-10 \%$ lower load-carrying capacity than the undamaged ones $-10 \%$ for the first test series and 5\% for the second. The average bond stress in the anchorage zone was about $16-17 \%$ lower in the beams with corrosion cracks compared with the $\mathrm{R}$ specimens, and $9-13 \%$ lower in the beams with cover spalling. It should also be noted that the concrete compressive strength $f_{\mathrm{c}}$ of the damaged specimens was slightly lower than that of the $\mathrm{R}$ 
Anchorage of naturally corroded bars in

reinforced concrete structures

Tahershamsi, Zandi, Lundgren and Plos

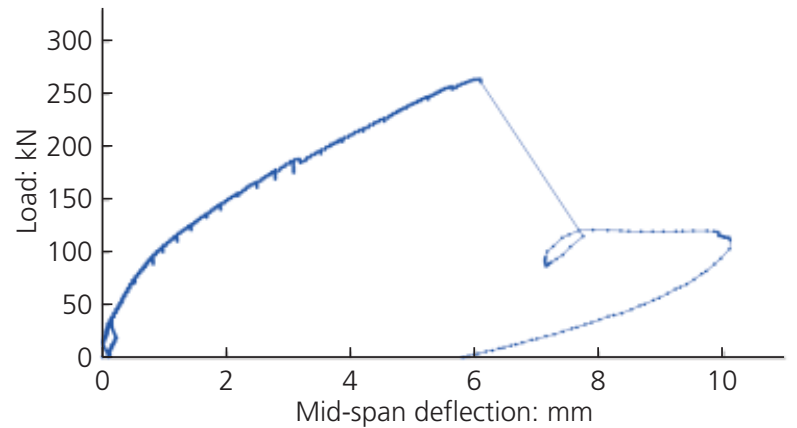

(a)

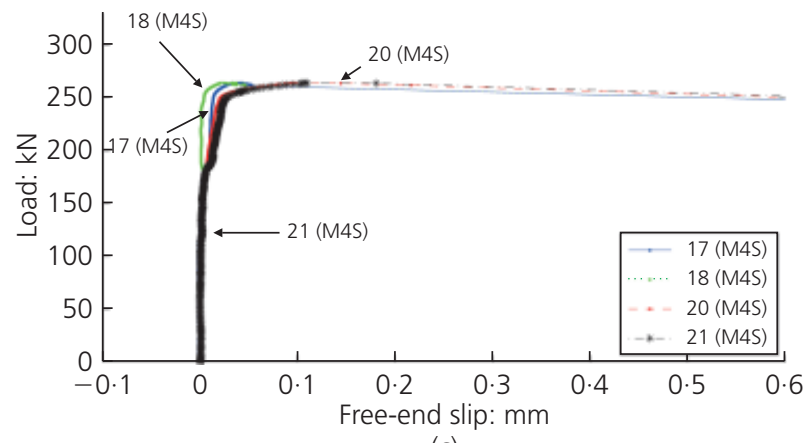

(c)

Figure 5. Test M4: (a) average load from hydraulic jacks versus measured deflection at mid-span (vertical mid-span displacement corrected for the support settlements); (b) average load from

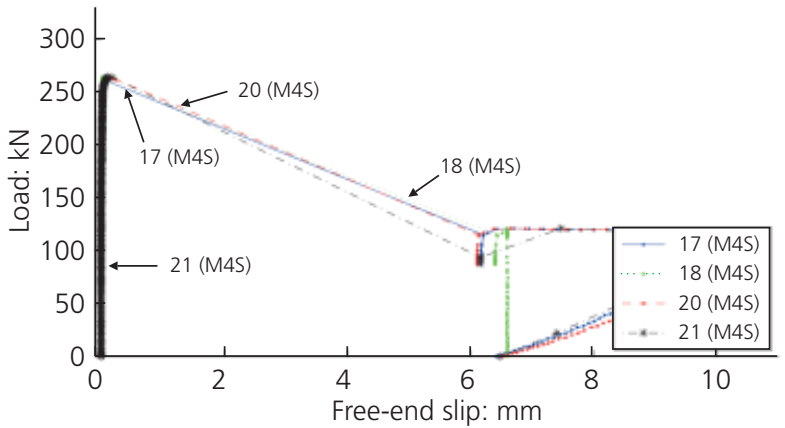

(b)

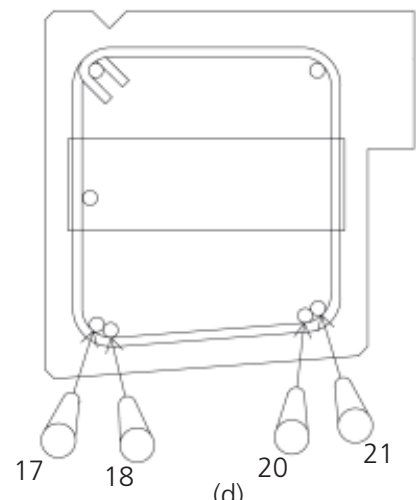

hydraulic jacks versus measured slips in each of the bundled bars; (c) enlarged part of Figure 5(b); (d) locations of the measuring transducers. M4S, south side of bar M4

\begin{tabular}{|c|c|c|c|c|c|c|c|c|c|}
\hline & \multicolumn{9}{|c|}{ Beam } \\
\hline & 4 & 5 & 6 & 7 & 8 & 9 & 10 & 11 & 12 \\
\hline $\mathrm{R}$ & $125-155$ & - & $160-170$ & - & - & - & - & - & - \\
\hline M & $155-185$ & $140-175$ & - & $155-185$ & $155-175$ & $120-173$ & $145-155$ & $155-170$ & $145-155$ \\
\hline $\mathrm{H}$ & - & $135-155$ & $135-145$ & $125-145$ & - & - & - & - & - \\
\hline
\end{tabular}

\begin{tabular}{|c|c|c|c|c|c|c|c|c|c|c|c|}
\hline & \multicolumn{9}{|c|}{ Beam } & \multirow[t]{2}{*}{ Average } & \multirow{2}{*}{$\begin{array}{l}\text { Standard } \\
\text { deviation }\end{array}$} \\
\hline & 4 & 5 & 6 & 7 & 8 & 9 & 10 & 11 & 12 & & \\
\hline$R$ & $240 \cdot 1$ & - & $322 \cdot 0$ & - & - & - & - & - & - & $281 \cdot 1$ & $57 \cdot 9$ \\
\hline M & $263 \cdot 0$ & 280.9 & - & $243 \cdot 3$ & $326 \cdot 8$ & $234 \cdot 2$ & 264.9 & $263 \cdot 2$ & 259.9 & $267 \cdot 0$ & $28 \cdot 0$ \\
\hline$H$ & - & $307 \cdot 6$ & $234 \cdot 9$ & $255 \cdot 3$ & - & - & - & - & - & $265 \cdot 9$ & $37 \cdot 5$ \\
\hline
\end{tabular}


Anchorage of naturally corroded bars in

reinforced concrete structures

Tahershamsi, Zandi, Lundgren and Plos

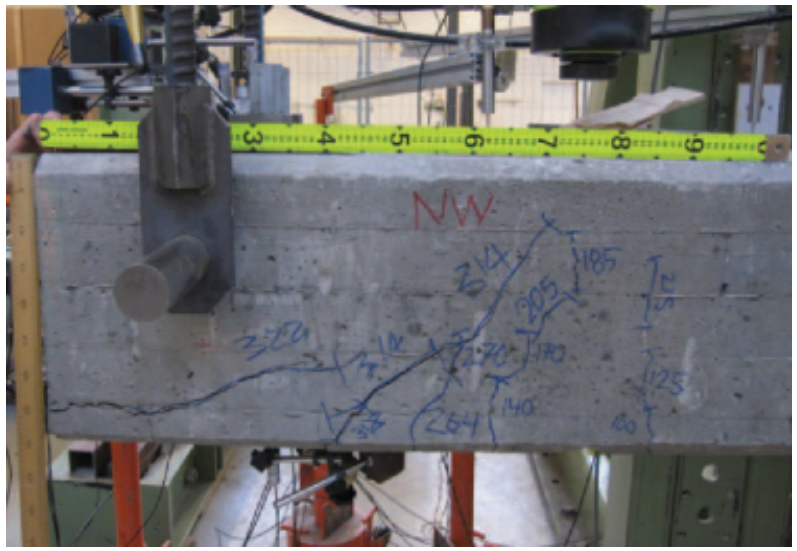

(a) R6

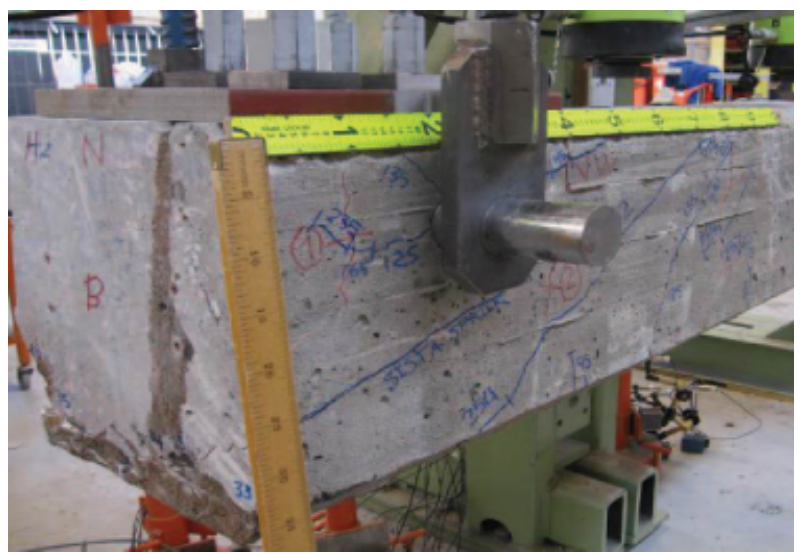

(c) H7, front

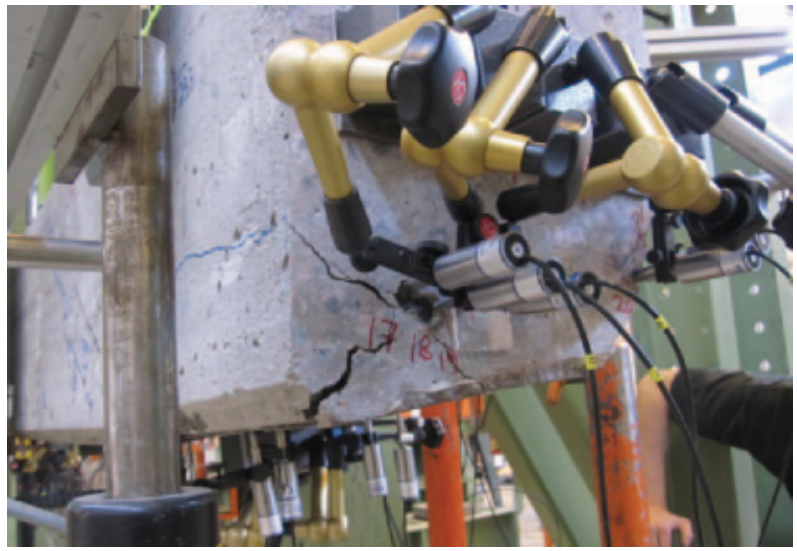

(b) M4

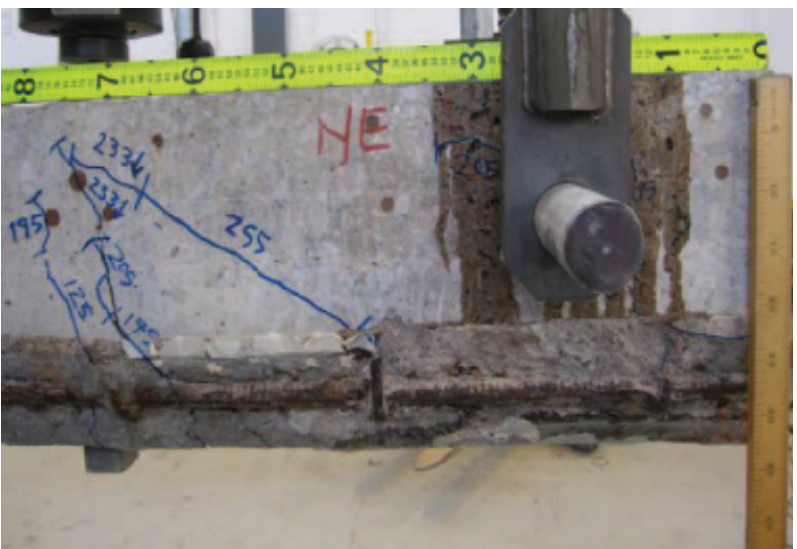

(d) H7, back

Figure 6. Failure and crack pattern of some of the beams after testing

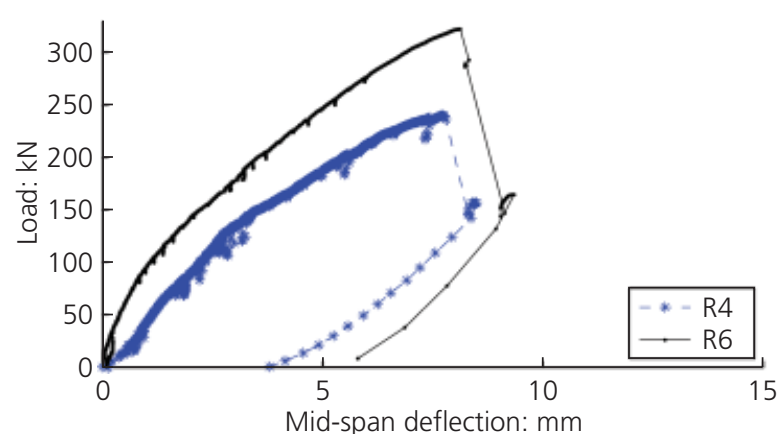

(a)

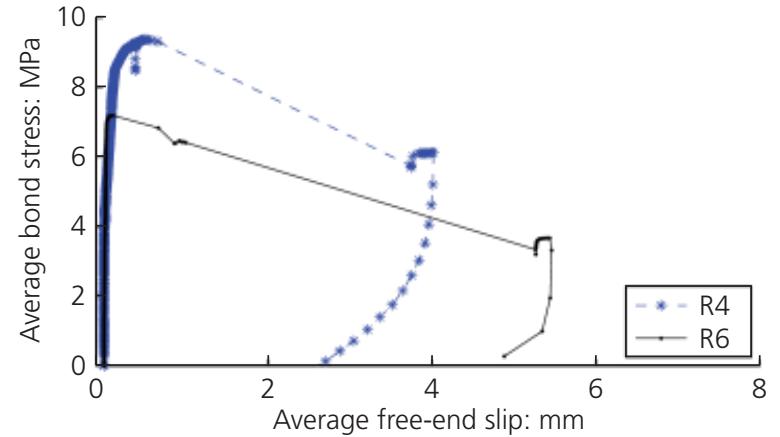

(b)

Figure 7. (a) Average load from hydraulic jacks versus measured deflection at mid span. (b) Average bond stress versus average measured free-end slip for $\mathrm{R}$ specimens

specimens; the samples from damaged specimens showed a 10 $15 \%$ reduction in strength.

In the $\mathrm{M}$ specimens, it was observed that anchorage failure occurred on the side where the widest splitting crack was located.
The maximum observed crack widths before structural testing were measured in the shear and anchorage zones in each specimen (Table 10). These values are plotted against the maximum average bond stress normalised using the average value of the $\mathrm{R}$ specimen in Figure 12. The results indicate decreasing bond 
Anchorage of naturally corroded bars in

reinforced concrete structures

Tahershamsi, Zandi, Lundgren and Plos

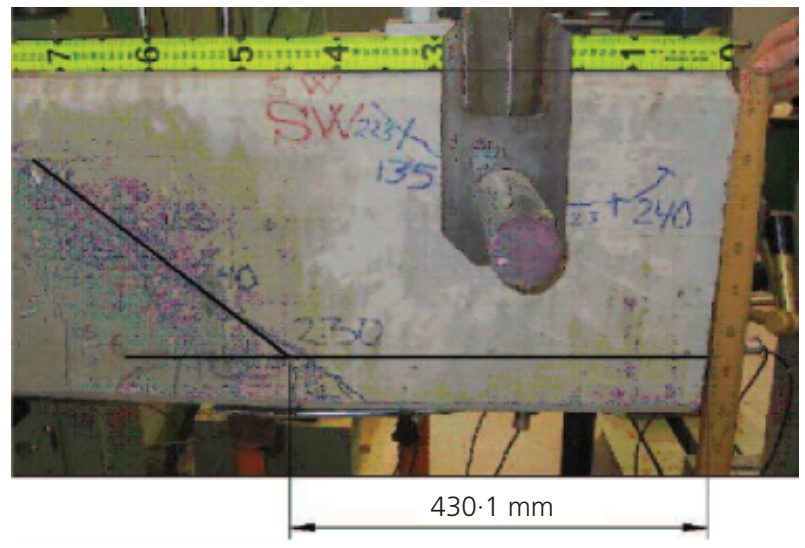

(a) M5

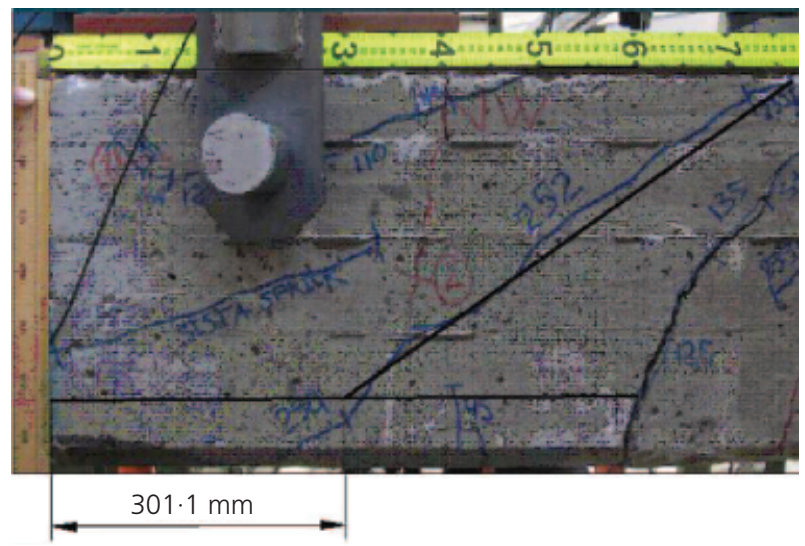

(c) $\mathrm{H} 7$, front side

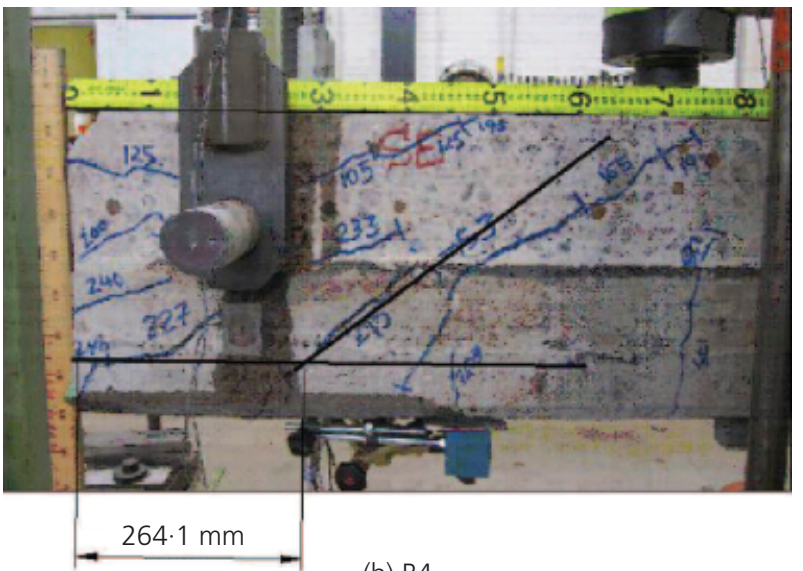

(b) R4

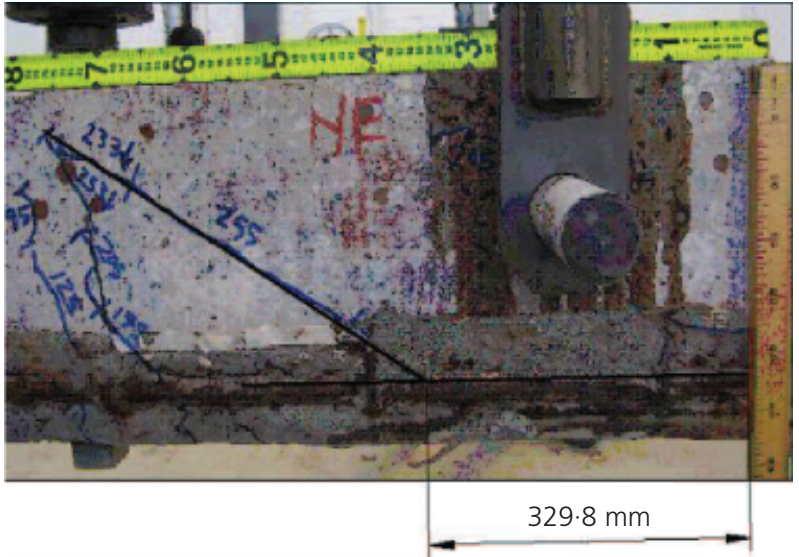

(d) H7, rear side

Figure 8. Available anchorage length in some of the beams, measured from the end cross-section to the point where the main bars and the inclined shear crack intersect

\begin{tabular}{|c|c|c|c|c|c|c|c|c|c|c|c|}
\hline & \multicolumn{9}{|c|}{ Beam } & \multirow[t]{2}{*}{ Average } & \multirow{2}{*}{$\begin{array}{l}\text { Standard } \\
\text { deviation }\end{array}$} \\
\hline & 4 & 5 & 6 & 7 & 8 & 9 & 10 & 11 & 12 & & \\
\hline $\mathrm{R}$ & 257 & - & 437 & - & - & - & - & - & - & 347 & 127 \\
\hline M & 426 & 431 & - & 314 & 341 & 337 & 334 & 507 & 501 & 399 & 78 \\
\hline $\mathrm{H}$ & - & 475 & 427 & 315 & - & - & - & - & - & 406 & 82 \\
\hline
\end{tabular}

capacity with increasing crack width. Model Code 2010 (fib, 2010) suggests a reduction in residual bond strength depending on the crack width and this is plotted for comparison in Figure 12. As Model Code 2010 gives a range for both bond strength and crack width, it was decided to plot the interval as the ranges in bond strength versus the average values of the relevant crack width ranges. As the figure shows, the upper and lower limits for the residual bond strength also have a descending trend with respect to the increase in crack width. It can be observed that the residual bond capacities of the naturally corroded specimens were higher than the upper limit in Model Code 2010.

Furthermore, in Figure 12, the results of the present study are compared with two different test series of accelerated corroded 


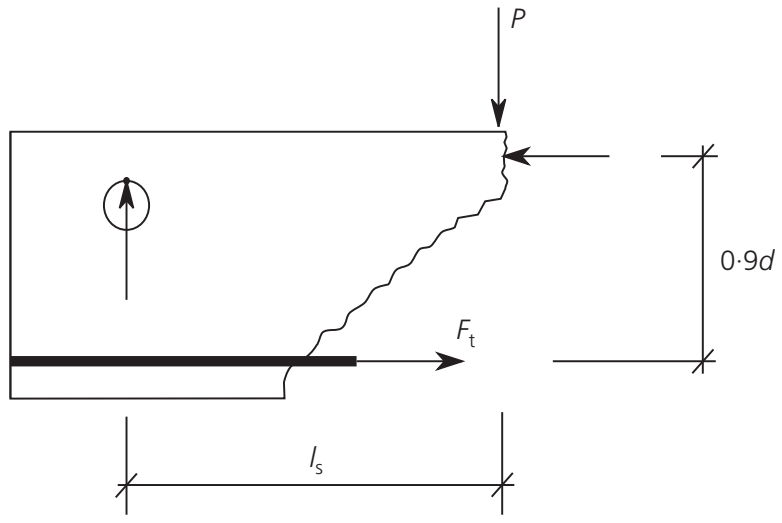

Figure 9. Notation used in estimation of the tensile force in the longitudinal reinforcement

specimens carried out by Rodriguez et al. (1994) and Zandi Hanjari and Coronelli (2010). The results from the naturally corroded specimens in this study and the artificially corroded tests are different. The bond strength of the naturally corroded bars was considerably higher than that of the artificially corroded specimens. It is worth mentioning that the range of measured crack widths in the naturally corroded samples was wider than with the artificially corroded specimens in the previous studies. Andrade and Alonso (1993) found that crack width depended not only on the corrosion level (reduction of bar cross-sectional area) but also on the applied current density (corrosion rate). For the same corrosion level and with low corrosion rates, larger crack widths appeared on the concrete surface.

As expected, the maximum average bond stress depends on the available anchorage length (Figure 13). The measured available anchorage length varied between 250 and $500 \mathrm{~mm}$ in the present study while it was fixed to a value of $210 \mathrm{~mm}$ in both the accelerated corrosion studies mentioned earlier. Furthermore, the artificially corroded specimens had a greater number of stirrups. It is therefore noteworthy that, for the same crack width, in spite of these differences, higher bond stresses were obtained in the naturally corroded tests than in the artificially corroded specimens.

Calculation of the stress in transverse and longitudinal reinforcements indicated that no yielding occurred until failure (Berg and
Johansson, 2011). To evaluate the amount of transverse reinforcement, a comparison was made with the provisions given in Eurocode 2 (CEN, 2004). The code requires that the area of transverse reinforcement in the anchorage zone is larger than $25 \%$ of the largest anchored bar or else the amount of transverse reinforcement will not be sufficient to contribute to the anchorage. In the tested specimens, there was only one stirrup with a bar diameter of $10 \mathrm{~mm}$ within the available anchorage length. This means that the area of the transverse reinforcement in the anchorage zone was only $19 \cdot 5 \%$ of the largest anchored bar. Therefore, according to Eurocode 2, the amount of transverse reinforcement is not sufficient to have an influence on the anchorage capacity.

\section{Corrosion measurements}

In the first test series, some specimens were broken and the tensile reinforcements removed. The bars were thoroughly cleaned in accordance with ASTM G1-03. The reinforcement bars removed from the damaged specimens showed severe pitting corrosion. The corrosion level was measured using a weight loss method. The weight loss in the corroded specimens was about 2$3 \%$ compared with that of an uncorroded specimen. In comparison with the tested reference bar, the yield strength of the corroded bars was reduced by $0 \cdot 5-20 \cdot 0 \%$, and the ultimate strength by $4-26 \%$. The ductility of the corroded bars was significantly reduced. For further details on these results, see Lundgren et al. (2014). In the second test series, all the broken specimens were saved for more accurate measurements of the corrosion level.

\section{Conclusion and outlook}

Thirteen specimens with varying degrees of natural corrosion were tested in an indirectly supported four-point bending test. In all the experiments, splitting-induced pull-out failure occurred after the appearance of diagonal shear cracks. Compared with undamaged reference specimens, the specimens with medium and high levels of damage had approximately 5\% lower load-carrying capacity. The maximum capacities in the reference beams showed a larger scatter. Specimens with relatively lower bending stiffness showed a more ductile bond failure. The available anchorage lengths were measured after the tests, between the intersection point of the main inclined shear crack and the tensile bars to the end cross-section; they varied from 250 to $500 \mathrm{~mm}$. The average

\begin{tabular}{cccccccccccccc}
\hline & \multicolumn{1}{c}{ Beam } & & & & Average & $\begin{array}{c}\text { Standard } \\
\text { deviation }\end{array}$ \\
\cline { 2 - 9 } & 4 & 5 & 6 & 7 & 8 & 9 & 10 & 11 & 12 & & \\
\hline $\mathrm{R}$ & 9.4 & - & 7.2 & - & - & - & - & - & - & 8.3 & 1.5 \\
$\mathrm{M}$ & 6.2 & 6.6 & - & 7.9 & $9 \cdot 3$ & 6.9 & 8.0 & $5 \cdot 2$ & $5 \cdot 2$ & 6.9 & 1.4 \\
$\mathrm{H}$ & - & 6.9 & 6.0 & 8.7 & - & - & - & - & - & 7.2 & 1.4
\end{tabular}

Table 9. Maximum average bond stress (in MPa) in the experiments 
Anchorage of naturally corroded bars in reinforced concrete structures

Tahershamsi, Zandi, Lundgren and Plos
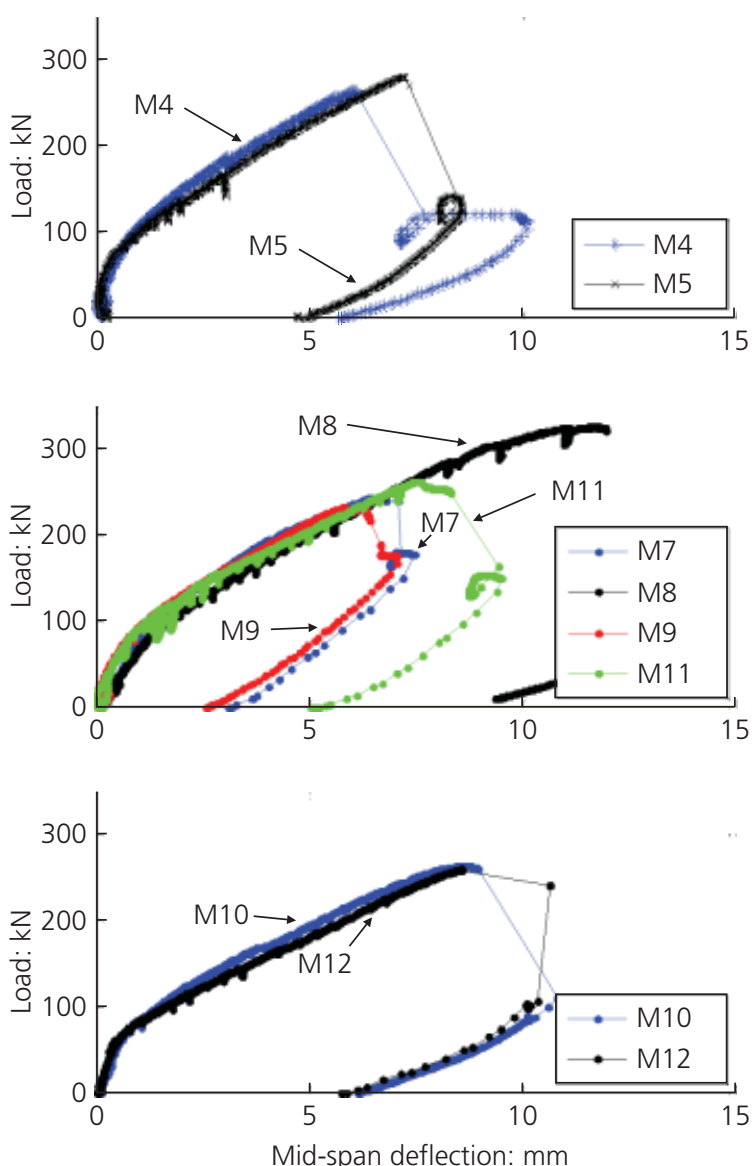

(a)

Figure 10. (a) Average load from hydraulic jacks versus measured deflection at mid-span. (b) Average bond stress versus average measured free-end slip for $\mathrm{M}$ specimens. The specimens were categorised into three groups regarding their bending stiffness
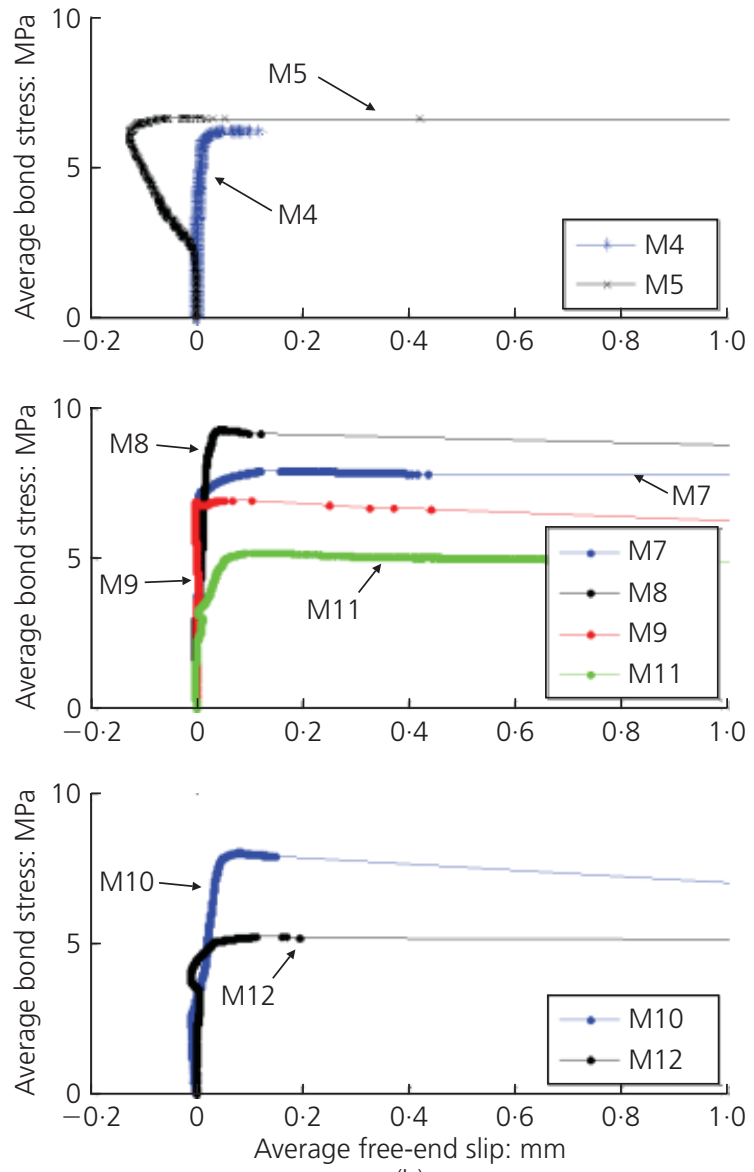

(b)

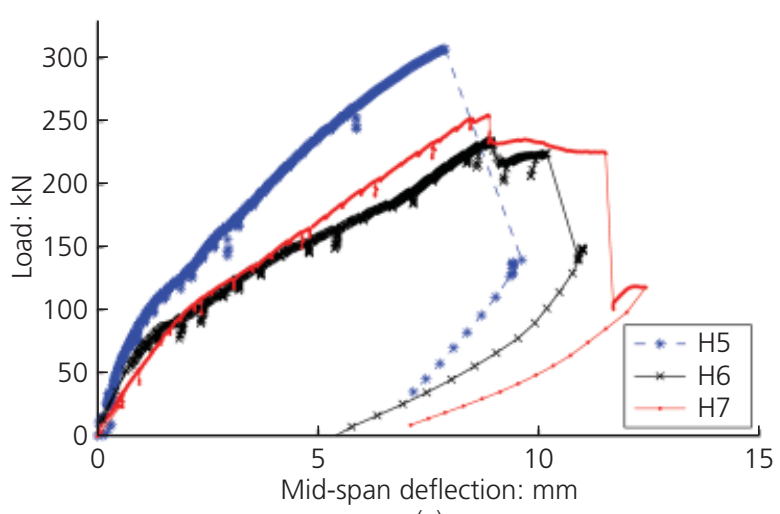

(a)

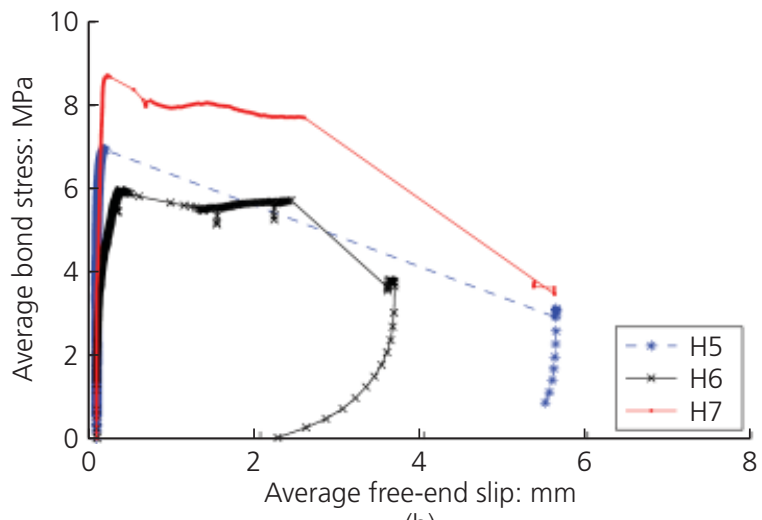

(b)

Figure 11. (a) Average load from hydraulic jacks versus measured deflection at mid-span. (b) Average bond stress versus average measured free-end slip for $\mathrm{H}$ specimens 


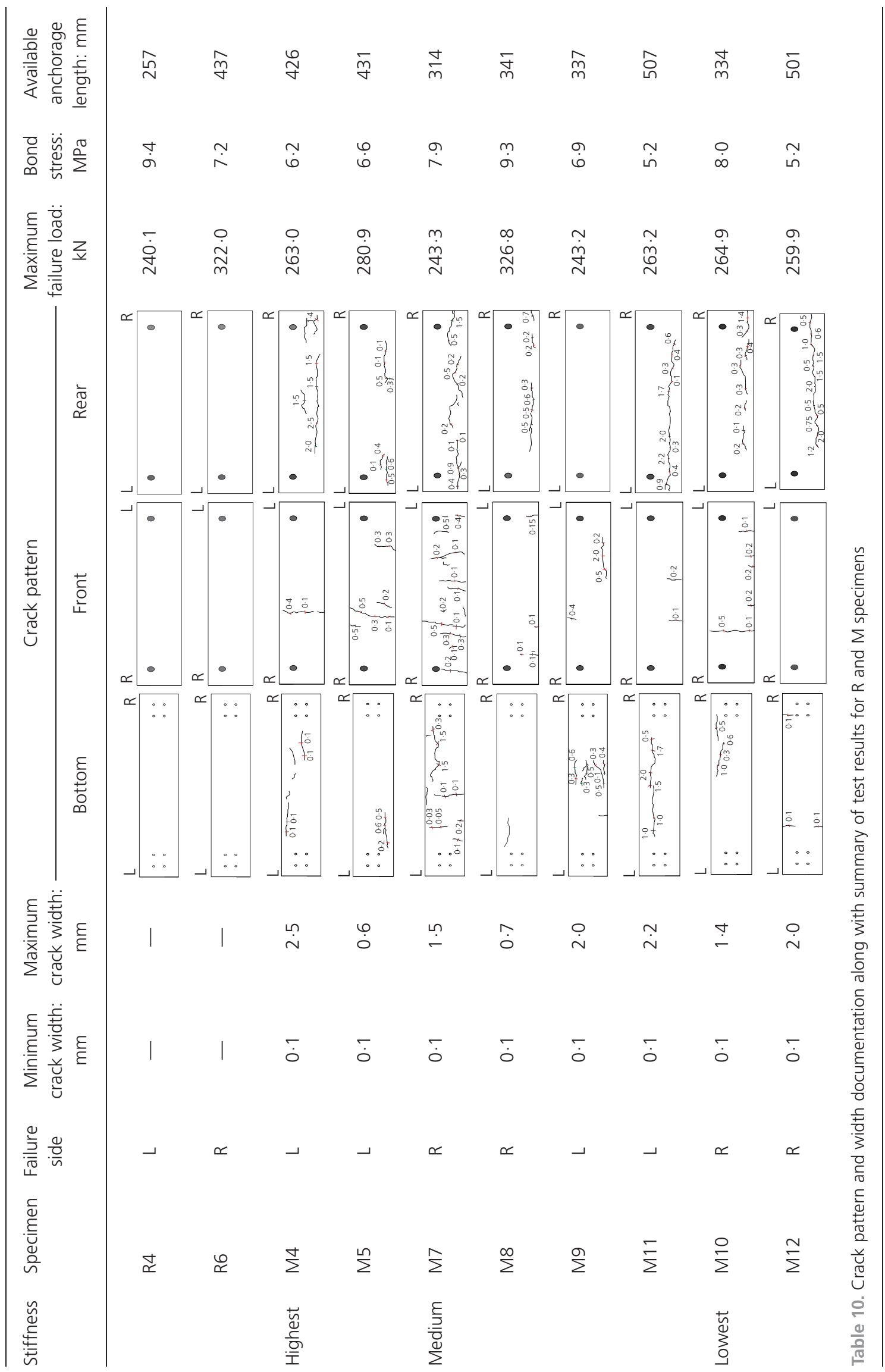




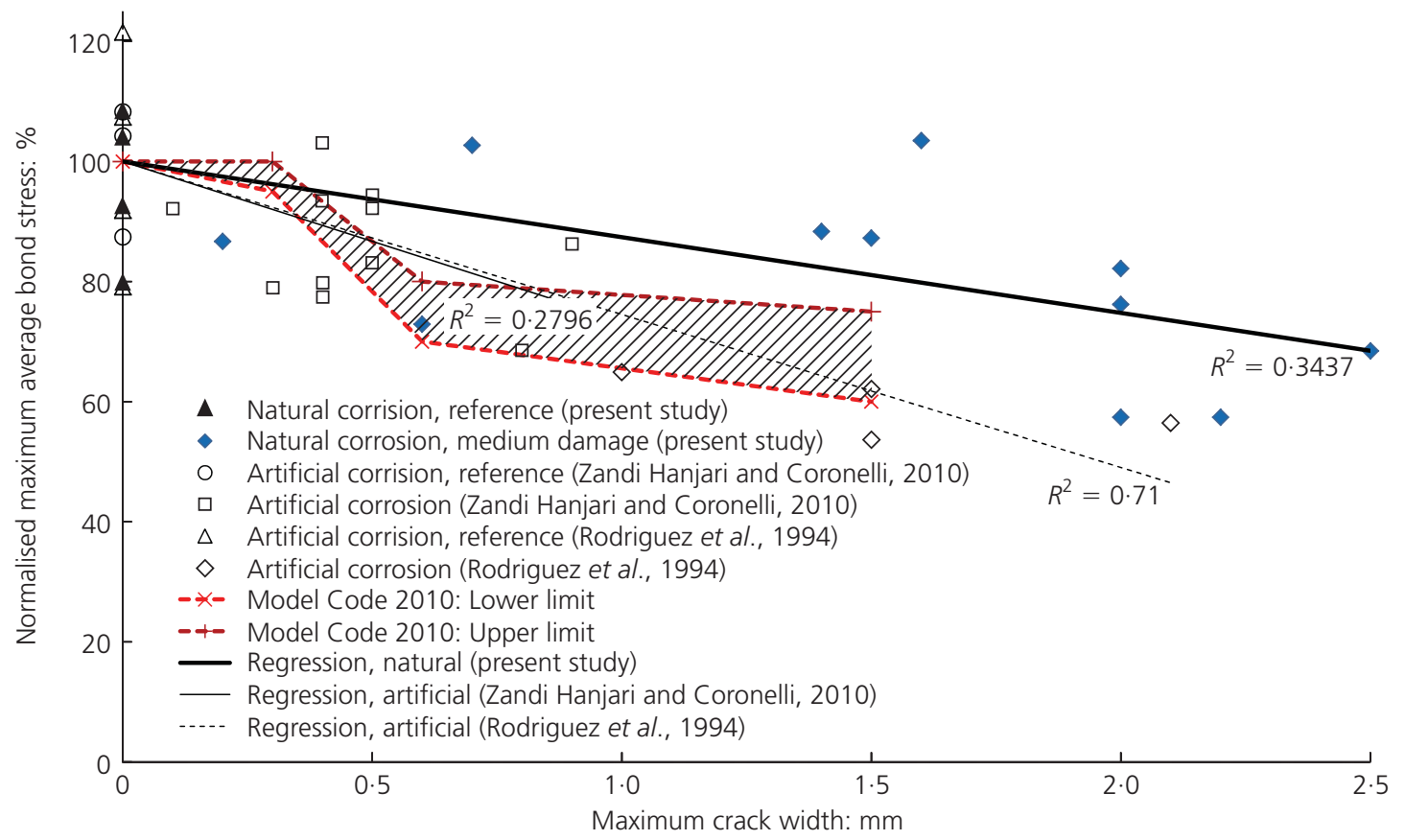

Figure 12. Comparison of test results from naturally corroded specimens with artificially corroded tests and with Model Code 2010 in terms of bond strength, normalised with respect to the average maximum bond strength obtained from $\mathrm{R}$ samples, versus maximum crack width

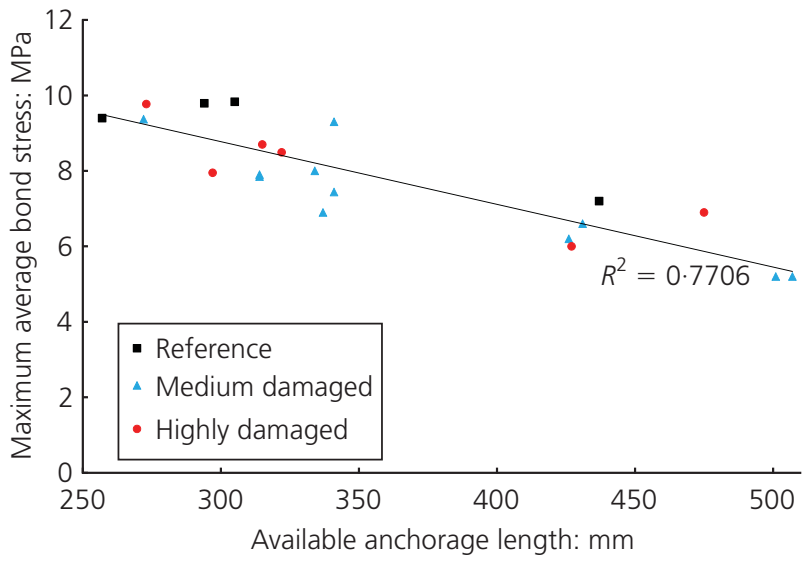

Figure 13. Maximum average bond stress in the anchorage zone versus the measured available anchorage length

bond stress in the anchorage area was calculated from the applied load and the available anchorage length. The values obtained showed a $17 \%$ reduction in average bond stress in specimens with cover cracking only (medium damage) and 13\% for the beams with cover spalling (high damage) compared with the reference beams. Material tests on the concrete showed a $10-15 \%$ strength reduction in compressive strength of the damaged specimens. Comparison of the results from artificial and natural corrosion showed both similarities and differences in the mechanical behaviour of reinforced concrete members. In both accelerated and natural corrosion, a reduction in residual bond strength was observed for increased maximum measured crack widths. Model Code 2010 (fib, 2010) also reports such a trend. However, the residual bond strength in the naturally corroded specimens was considerably higher than both the artificially corroded specimens and the limits given in Model Code 2010.

The tests conducted in this research have produced benchmark data for anchorage behaviour in naturally corroded reinforcements. For a better understanding of the mechanical behaviour of natural corrosion, the test results obtained will be evaluated using a more advanced method than the one used thus far - the new datasets will be analysed with advanced 3D finite-element models utilising the available bond and corrosion models developed by Lundgren (2005) and Zandi Hanjari et al. (2011a). In the work described in this paper, specimens were qualitatively classified through damage observations. Therefore, for detailed study of the corrosion levels, the conventional methods of weight loss should be complemented with more advanced volumetric 3D scanning measurements. The results from the two test series reported here and elsewhere (Lundgren et al., 2014) have yielded valuable information on the anchorage behaviour in naturally corroded concrete structures. However, considering that the results differ from artificially corroded specimens, more tests on naturally corroded structures are still needed.

\section{Acknowledgements}

This work was undertaken at Chalmers University of Technology, Division of Structural Engineering, Concrete Structures. The 
authors would like to acknowledge the funding from the Swedish Transport Administration (Trafikverket).

\section{REFERENCES}

Almusallam AA (2001) Effect of degree of corrosion on the properties of reinforcing steel bars. Construction and Building Materials 15(8): 361-368.

Al-Sulaimani GJ, Kaleemullah M, Basunbul IA et al. (1990) Influence of corrosion and cracking on bond behavior and strength of reinforced concrete members. ACI Structural Journal 87(2): 220-231.

Andrade C and Alonso C (1993) Cover cracking as a function of bar corrosion: part I - experimental test. Materials and Structures 26(8): 453-464.

ASTM (2003) ASTM:GI-03: Standard practice for preparing, cleaning and evaluating corrosion test specimens. ASTM International, West Conshohocken, PA, USA.

Austin SA, Lyons R and Ing MJ (2004) Electrochemical behavior of steel-reinforced concrete during accelerated corrosion testing. Corrosion 60(2): 203-212.

Berg F and Johansson D (2011) Design of Test Set-up Using FEM Pilot Tests on Anchorage of Naturally Corroded Reinforcement. Chalmers University of Technology, Gothenburg, Sweden.

BSI (2009a) BS EN 12504-1: 2009 Testing concrete in structures. Cored specimens. Taking, examining and testing in compression. BSI, London, UK.

BSI (2009b) BS EN 12390-3: 2009 Testing hardened concrete. Compressive strength of test specimens. BSI, London, UK.

CEN (Comité Européen de Normalisation) (2004) Eurocode 2: Design of concrete structures. Part 1: general rules and rules for buildings. CEN, Brussels, Belgium.

Coronelli D (1997) Bond of corroded bars in confined concrete: test results and mechanical modelling. Studi e Ricerche della Scuola di Specializzaziona in Costruzioni in c. a. Politecnico di Milano 18: 137-211.

Coronelli D and Gambarova P (2004) Structural assessment of corroded reinforced concrete beams: modeling guidelines. Journal of Structural Engineering 130(8): 1214-1224.

Coronelli D, Hanjari KZ and Lundgren K (2013) Severely corroded RC with cover cracking. Journal of Structural Engineering 139(2): 221-232.

Du YG, Clark LA and Chan AHC (2005a) Effect of corrosion on ductility of reinforcing bars. Magazine of Concrete Research 57(7): 407-419.

Du YG, Clark LA and Chan AHC (2005b) Residual capacity of corroded reinforcing bars. Magazine of Concrete Research 57(3): 135-147.

fib (International Federation for Structural Concrete) (2010) Model Code 2010, Vol. 1. fib, Lausanne, Switzerland.

Gestsdottir E and Gudmundsson T (2012) Bond Behaviour of Naturally Corroded Reinforcement in Concrete Structures. Chalmers University of Technology, Gothenburg, Sweden. Jirsa JO, Chen W, Grant DB and Elizondo R (1995) Development of Bundled Reinforcing Steel. The University of Texas at Austin, Austin, TX, USA.

Lundgren K (2005) bond between ribbed bars and concrete. Part 2: The effect of corrosion. Magazine of Concrete Research 57(7): 383-395.

Lundgren K, Tahershamsi M, Zandi Hanjari K and Plos M (2014) Tests on anchorage of naturally corroded reinforcement in concrete. Journal of Materials and Structures. Published online. See http://link.springer.com/article/10.1617/s11527014-0290-y (accessed 15/05/2014).

Magnusson J (2000) Bond and Anchorage of Ribbed Bars in High-Strength Concrete. Chalmers University of Technology, Gothenburg, Sweden.

Regan PE and Kennedy Reid IL (2010) Assessment of Concrete Structures Affected by Delamination - 2. Graduate School in Concrete Structures, Politecnico di Milano, Milan, Italy.

Rodriguez J, Ortega LM and Garda AM (1994) Assessment of structural elements with corroded reinforcement. In Proceedings of International Conference on Corrosion and Corrosion Protection of Steel in Concrete, Sheffield, UK (Swamy RN (ed.)). Sheffield Academic Press Ltd., Sheffield, UK pp. 171-185.

Sæther I (2011) Bond deterioration of corroded steel bars in concrete. Structure and Infrastructure Engineering 7(6): 415429.

Saifullah M and Clark LA (1994) Effect of corrosion rate on the bond strength of corroded reinforcement. In Proceedings of International Conference on Corrosion and Corrosion Protection of Steel in Concrete, Sheffield, UK (Swamy RN (ed.)). Sheffield Academic Press Ltd., Sheffield, UK, pp. 591-602.

Tahershamsi M, Zandi Hanjari K, Lundgren K and Plos M (2012a) Anchorage capacity of naturally corroded reinforced concrete beams. In Proceedings of fib Symposium on Concrete Structures for Sustainable Community (Bager DH and Silfwerbrand J (eds)). fib, Stockholm, Sweden, pp. 323-326.

Tahershamsi M, Zandi Hanjari K, Lundgren K and Plos M (2012b) Anchorage in naturally corroded specimens taken from existing structures. In Bond in Concrete 2012: Bond, Anchorage, Detailing. Fourth International Symposium, Volume 1: General Aspects of Bond (Cairns JW, Metelli G and Plizzari GA (eds)). Manerbio, Brescia, Italy, pp. 345-349.

Val DV, Chernin L and Stewart MG (2009) Experimental and numerical investigation of corrosion-induced cover cracking in reinforced concrete structures. Journal of Structural Engineering 135(4): 376-385.

Yuan Y, Ji Y and Shah SP (2007) Comparison of two accelerated corrosion techniques for concrete structures. ACI Structural Journal 104(3): 344-347.

Zandi Hanjari K and Coronelli D (2010) Anchorage Capacity of Corroded Reinforcement. Eccentric Pull-out Tests. Chalmers University of Technology, Gothenburg, Sweden.

Zandi Hanjari K, Coronelli D and Lundgren K (2011a) Bond capacity of severely corroded bars with corroded stirrups. Magazine of Concrete Research 63(12): 953-968. 
Zandi Hanjari K, Kettil P and Lundgren K (2011b) Analysis of mechanical behavior of corroded reinforced concrete structures. ACI Structural Journal 108(5):

$532-541$.
Zandi Hanjari K, Kettil P and Lundgren K (2013) Modelling the structural behaviour of frost-damaged reinforced concrete structures. Structure and Infrastructure Engineering 9(5): 416-431.

\section{WHAT DO YOU THINK?}

To discuss this paper, please submit up to 500 words to the editor at journals@ice.org.uk. Your contribution will be forwarded to the author(s) for a reply and, if considered appropriate by the editorial panel, will be published as a discussion in a future issue of the journal. 